\title{
Analisis Disparitas Wilayah di Provinsi Aceh: Telaah pada Dana Otonomi Khusus
}

\author{
Devi Andriyani*a, Hijri Juliansyah ${ }^{* b}$ \\ *Fakultas Ekonomi dan Bisnis Universitas Malikussaleh \\ a Corresponding author: devisep80@gmail.com \\ b hijri.juliansyah@gmail.com
}

ART I CLE INFORMATION

Keywords:

Disparity, OTSUS, Expenditure
A B S T R A C T

This study wants to identify the model of regional disparity in Aceh in terms of the OTSUS Aceh fund allocation policy. Specific research aims to determine the OTSUS fund allocation policy model that avoids disparity between districts / cities. The analysis model uses the formulation of theil index region disparity index which is then carried out multiple linear regression estimation panel data estimation. The results of the study indicate that the disparity in Aceh Province during the OTSUS period has decreased. Disparity is absorbed predominantly in the intra-region (within region) group in the South West, Middle East, and North East. The allocation of OTSUS funds has a significant impact in reducing regional disparity, both in time series and panel analysis. The results of the study concluded that the gap that occurred in Aceh Province was due to the weak factor in providing basic needs, such as education and health. Therefore, the management of OTSUS funds must be carried out precisely in improving aspects of education and health services in Aceh Province.

\section{PENDAHULUAN}

Kebijakan otonomi daerah telah menjadikan Indonesia sebagai negara dengan sistem pengelolaan keuangan yang berbasis desentralisasi. Penerapan desentralisasi fiskal tersebut memiliki tujuan untuk meningkatkan pertumbuhan ekonomi serta peningkatan pendapatan daerah. Hubungan keuangan antara pusat dan daerah telah mendorong adanya desentralisasi fiskal dimana pemerintah pusat saat ini telah mengalokasikan Dana Perimbangan (DP) untuk membiayai kebutuhan daerah dalam rangka mendukung pelaksanaan pembangunan Salah satu alasan utama mengapa peran dana transfer dari pusat sedemikian pentingnya adalah untuk menjaga/menjamin tercapainya standar pelayan publik minimum di seluruh negeri dan mengurangi kesenjangan antar daerah (Simanjuntak, 2001). Berkaitan dengan desentralisasi fiskal, Thie Ben (2003) memberi pandangan tentang kelemahan pelaksanaan desentralisasi fiskal yang diantaranya; desentralisasi fiskal dapat memperkuat kesenjangan regional (regional inequality) dan menghambat pertumbuhan ekonomi, karena perbedaan atas tingkat pendapatan dan basis pajak antara wilayah dan daerah.

$$
\text { Studi Akai dan Sakata }
$$

menghasilkan temuan bahwa desentralisasi fiskal terutama desentralisasi penerimaan, memberikan sugesti pembangunan kedepan serta memberikan stimulasi pertumbuhan ekonomi. Beberapa hasil studi lainnya, seperti Martinez-Vazquez dan McNab (2006) menjelaskan bawah desentralisasi fiskal berkorelasi negatif terhadap pertumbuhan ekonomi di negera developing

Todaro (2000) dalam Riyanto (2003) mengemukakan bahwa besarnya dana perimbangan dan distribusi setelah desentralisasi yang diberikan oleh pemerintah pusat ke pemerintah daerah barulah merupakan syarat perlu (necessary condition). Syarat cukupnya (sufficient condition) adalah bagaimana proses perencanaan 
dilakukan, bagaimana pengelolaan anggaran/keuangan di daerah, bagaimana respon pemerintah dan bagaimana sumberdaya manusianya serta kelembagaan ekonomi yang ada di daerah (Riyanto, 2003).

Provinsi Aceh menjadi daerah dengan perolehan dana perimbangan yang besar melalui pengalokasian dana tambahan Otonomi Khusus untuk membiayai kegiatan pembangunan. Namun demikian, pada kenyataannya pengelolaan dana Otsus terus mengalami tarik ulur dalam implementasinya. Sejak tahun 2008, dana Alokasi dana OTSU mengalami perubahan-perubahan mendasar dalam tata kelolanya.

Dalam perkembangannya, Qanun OTSUS Aceh terus mengalami perubahan dan perbaikan tata kelola hingga dikeluarkannya pengelolaan dana Otsus Aceh Qanun No. 2 tahun 2008 dan Keputusan Gubernur No. 48 tahun 2009. Pada periode tahun 2013 terjadi perubahan tata kelola OTSUS Aceh dengan diterbitkannya aturan Qanun No. 2 tahun 2013 Tentang Tata Cara Pengalokasian Tambahan Dana Bagi Hasil Minyak dan Gas Bumi Dan Penggunaan Dana Otonomi Khusus.

Perubahan terakhir terjadi pada tahun 2016 yang ditandai dengan disahkannya Qanun No. 10 tahun 2016 Tentang Perubahan Kedua Atas Qanun Aceh Nomor 2 Tahun 2008 Tentang Tata Cara Pengalokasian Tambahan Dana Bagi Hasil Minyak Dan Gas Bumi Dan Penggunaan Dana Otonomi Khusus. Berikut ini gambaran perubahanperubahan Qanun Aceh yang berkaitan dengan Pengelolaan dana OTSUS.

Penelitian ini berusahan untuk menguraikan secara deskriptif tata kelola dana Otsus Aceh dan distribusi anggaran pada tiap sektor pembangunan. Urgensinya adalah, jika dihadapkan pada berbagai perubahan tata kelola maka basis pengembangan sektor strategis dikhawatirkan akan mengalami gangguan. Maka rumusan masalah yang ingin dijawab dalam penelitian ini adalah; (1) apakah alokasi dana otsus mampu menurunkan indeks disparitas wilayah di Provinsi Aceh? (2) Bagaimana pengaruh belanja pembangunan terhadap disparitas di Provinsi Aceh?

\section{TINJAUAN TEORITIS}

Kebijakan dana otsus Aceh merupakan salah satu bentuk dari desentralisasi fiskal melalui transfer keuangan pusat-daerah untuk mencapai target pemerataan pembangunan. Pendapatan daerah bersumber dari pendapatan asli daerah, dana perimbangan, dana otonomi khsusus, pendapatan lain-lain yang sah (Yani, 2009). Dasar hukum dari kebijakan dana Otsus terdiri dari UU No. 11 tahun 2006 Tentang Pemerintahan Aceh. Beberapa pertimbangan yang menjadi konsideran lahirnya UU No. 11 Tahun 2006 menurut Yani (2009), terdiri dari:

1. Sistem pemerintahan Negara Kesatuan Republik Indonesia menurut Undang-Undang Dasar Negara Republik Indonesia tahun 1945 mengakui dan mengormati satuan-satuan pemerintahan daerah yang bersifat khusus atau bersifat istimewa yang diatur dengan undang-undang.

2. Aceh merupakan satuan pemerintahan daerah yang bersifat khusus atau istimewa terkait dengan salah satu karakter khas sejarah perjuangan masyarakat Aceh.

3. Adanya pandangan hidup yang berlandaskan syatiah Islam yang melahirkan budaya Islam yang kuat, sehingga Ace menjadi daerah modal bagi perjuangan Indonesia.

4. Penyelenggaraan pemerintahan dan pelaksanaan pembangunan Aceh belum dapat sepenuhnya mewujudkan kesejahteraan rakyat, keadilan, pemenuhan, dan perlindungan hak asasi manusia.

5. Bencana gempa bumi dan tsunami telah menumbuhkan solidaritas bangsa untuk membangun kembali Aceh serta menyelesaikan konflik secara damai, menyeluruh, dan berkelanjutan.

Musmualim (2010) dalam penelitiannya "Pengaruh Desentralisasi Fiskal Terhadap Pertumbuhan Ekonomi dan Peran Kelembagaa Dana Otonomi Khusus Papua Di Provinsi Papua Barat" menghasilkan temuan bahwa Dana Otonomi Khusus Papua tidak berpengaruh signifikan terhadap pertumbuhan ekonomi untuk seluruh kabupaten/kota di Provinsi Papua Barat. Meskipun sifat Dana Otonomi Khusus Papua 
merupakan special grant, di mana peruntukan pemanfaatan dana tersebut telah ada peraturannya, namun hasil penelitian ini menunjukkan bahwa pemerintah kabupaten/kota di Provinsi Papua Barat belum mampu secara optimal memanfaatkan Dana Otonomi Khusus Papua untuk mendorong pertumbuhan ekonomi.

\section{METODE PENELITIAN}

Desain penelitian dilakukan dengan analisis disparitas dan model regresi linear berganda data panel. Periode analisis dilakukan dalam rentang tahun 2008-2016 yang dibagi dalam 3 kelompok wilayah; Barat Selatan, Tengah Tenggara, dan Timur Utara.

Ruang lingkup penelitian terdiri dari: (1)Pengukuran Disparitas pendapatan antar wilayah melalui indeks theil dari tahun 2008-2016;

(2) Model analisa regresi linear berganda dengan perumusan data panel.

Perumusan Disparitas Pendapatan Antar Wilayah Indeks Entrophy Theil

$$
\mathrm{I}(\mathrm{y})=\sum_{\mathrm{r}=1}^{\mathrm{R}} \log \frac{\mathrm{Y}_{\mathrm{r}}}{\mathrm{N}_{\mathrm{r}} / \mathrm{N}}+\sum_{\mathrm{r}=1}^{\mathrm{R}} \mathrm{Y}_{\mathrm{r}}\left[\sum_{\mathrm{i} \in \mathrm{r}} \frac{\mathrm{y}_{\mathrm{i}}}{\mathrm{y}_{\mathrm{r}}} \log \frac{\mathrm{y}_{\mathrm{i}} / \mathrm{Y}_{\mathrm{r}}}{\mathrm{N}_{\mathrm{r}}}\right]
$$

(Kuncoro, 2013)

dalam

$\mathrm{Y}_{\mathrm{r}}=$ Pangsa PDRB Seluruh Kab/kota

$$
\text { wilayah } r
$$

$\mathrm{y}_{\mathrm{i}}=$ Pangsa PDRB kab/kota terhadap total PDRB Provinsi Aceh

$\mathrm{N}_{\mathrm{r}}=$ Jumlah kab/kota dalam wilayah $\mathrm{r}$

$\mathrm{N}$ = Jumlah keseluruhan kab/kota Provinsi Aceh

$\mathrm{R}=$ Jumlah keseluruhan wilayah Provinsi Aceh

$\mathrm{r}=$ terdiri dari wilayah barat selatan tengah tenggara, dan timur utara

\section{Analisa Regresi Linear berganda}

Analisa dampak dilakukan dengan model ekonometrika regresi linear berganda, yang berguna untuk menguju hubungan/pengaruh indeks antar varible bebas dan terikat. Model regresi data panel yang menjelaskan hubungan antara indeks disparitas wilayah entrophy theil dengan alokasi jumlah dana Otsus yang diterima sejak tahun 2008. Estimasi data dilakukan dengan mengklasifikasi daerah kedalam kelompok tiga wilayah, yaitu Barat Selatan, tengah Tenggara, dan Timur Utara.

$Y_{i t}=a_{i t}+b_{1} B E_{i t}+b_{2} B P_{i t}+b_{3} B K_{i t}+$ b4BPUBL Bit + b5OTSUS $_{i t}+e_{i t}$

Keterangan:

I : Menunjukkan data cross section wilayah Barat Selatan,Tengah Tenggara, dan Timur Utara

T : Menunjukkan dimensi deret waktu(20082016)

$\mathrm{a}_{\mathrm{it}} \quad$ : Koefisien intersep (konstanta)

$\mathrm{Y}_{\text {it }} \quad$ : Indeks Disparitas wilayah Entrophy Theil

BE : Belanja berdasarkan fungsi ekonomi

BP : Belanja berdasarkan fungsi Pendidikan

BK : Belanja berdasarkan fungsi kesehatan

BPUBL: Belanja berdasarkan pelayanan publik OTUS : Jumlah alokasi dana OTSUS $\mathrm{e}_{\mathrm{it}} \quad$ : error

\section{HASIL PENELITIAN DAN PEMBAHASAN}

\section{Kondisi Dispritas Provinsi Aceh}

Telaah disparitas menggunakan indeks pengukuran Entrophy Theil. Berdasarkan pengukuran yang dilakukan kecenderungan yang terjadi adalah, indeks kesenjangan cenderung mengalami penurunan dalam periode waktu 20002016. Namun penurunan tersebut masih menempatkan Aceh pada posisi dengan indeks kesenjangan yang moderat. Berikut ini grafik pengukuran dari Indeks kesenjangan dengan metode pengukuran Williamson dan theil.

\section{Gambar 1}


Trend Disapritas Provinsi Aceh

Berdasarkan Ukuran Indeks Entrophy Theil

Tahun 2008-2016

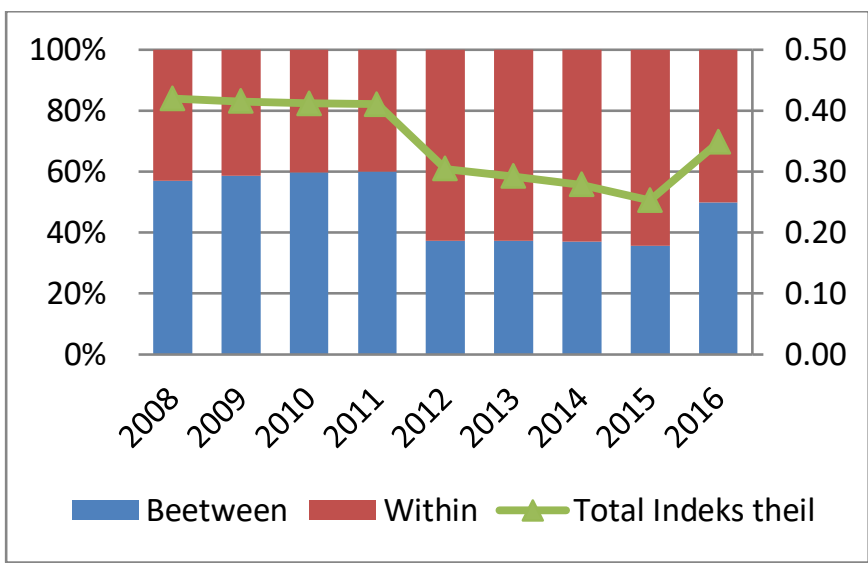

Sumber: Data PDRB Kabupaten/kota Provinsi Aceh, 2008-2016 (diolah)

Kesenjangan yang terjadi di Provinsi Aceh menunjukkan adanya trend penurunan sejak tahun 2011. Hal ini diduga sebagai efek dari adanya pembangunan melalui sejumlah dana perimbangan yang besar, khususnya dana OTSUS. Adapun kekhawatiran yang terjadi dari hasil deskripsi kesenjangan Aceh, terlihat mengalami kenaikan pada periode tahun 2014-2016.

Meskipun dana OTSUS sudah dialokasikan sejak tahun 2008, tingkat kesenjangan masih tinggi dengan nilai rata-rata sebesar 0,36. Besar kemungkinan indeks kesejangan yang terjadi, diserap oleh daerah yang belum mampu mengelola anggaran dengan prudent dan tingginya belanja rutin. Justifikasi lain kesenjangan yang terjadi, diperkirakan akibat banyaknya industri migas yang mengalami penurunan dan terus menipis.

Jika didekomposisikan lebih lanjut, disparitas terserap lebih dominan pada kelompok intra wilayah yang teradap di Barat Selatan, Tengah Tenggara, dan Timur Utara. Hasil perhtiungan ini membuktikan bahwa disparitas wilayah yang terjadi di Provinsi Aceh tidak bersumber dari lingkup antar wilayah Barat Selatan, Tengah Tengagra, dan Timur Utara. Kesejangan yang tinggi ini terjadi pada lingkup didalam wilayah-wilayah itu sendiri. Maka dari itu, Peneliti memandang adanya keinginan pemisahan wilayah Aceh Barat Selatan (ABAS) dan Aceh Leuser Antara (ALA) yang diargumentasikan sebagai akibat dari kesenjangan wilayah, tidak memiliki argumentasi ekonomi yang kuat (Maulana, 2016)

\section{Tabel 1}

\section{Hasil Estimasi Model Kesenjangan Wilayah Beetwen Index Theil}

Sumber: Diolah oleh penulis dengan e-views ver

\begin{tabular}{|c|c|c|c|}
\hline \multirow[t]{2}{*}{ Variabel } & \multicolumn{3}{|c|}{$\begin{array}{c}\text { Dependet Variabel Beetwen } \\
\text { Index Theil }\end{array}$} \\
\hline & Koef & Std.Error & T-Stat \\
\hline $\begin{array}{l}\text { Constant } \\
\text { Parameter } \\
\text { (C) }\end{array}$ & 0,13 & 0,03 & $\begin{array}{l}3,53 \\
(* * *)\end{array}$ \\
\hline OTSUS & $-3,64$ & 5,66 & $-0,64$ \\
\hline ECON_EXP & 2,06 & 8.33 & $\begin{array}{l}2,47 \\
(* *)\end{array}$ \\
\hline PUBL_EXP & 2,07 & 1,42 & 1,46 \\
\hline $\begin{array}{l}\text { HEALTH_E } \\
\text { XP }\end{array}$ & -6.5 & 4,84 & $-1,34$ \\
\hline EDUC_EXP & $-8,09$ & 2,8 & $\begin{array}{l}-2,89 \\
(* * *)\end{array}$ \\
\hline $\mathrm{R}^{2}$ & \multicolumn{3}{|c|}{0,98} \\
\hline F-Stat & \multicolumn{3}{|c|}{$\begin{array}{l}295,7 \\
(* * *)\end{array}$} \\
\hline Dw-Stat & \multicolumn{3}{|c|}{1,9} \\
\hline
\end{tabular}

8.0

Keterangan:***significant pada $\alpha 1 \%(\mathrm{p}<0.01)$; **significant pada a 5\% $(\mathrm{p}<0.05) ; *_{\text {significant }}$ pada $\alpha 10 \%(\mathrm{p}<0.1)$.

Analisis dilakukan dengan estimasi data panel pada 3 wilayah; Barat Selatan, Tengah Tenggara, dan Timur Utara selama jangka waktu periode OTSUS 2008-2016. Maka dalam permodelan kesenjangan Indeks Theil ini, terdapat dua model utama yang merangkum hasil pengolahan kesenjangan di provinsi Aceh:

1. Kesenjangan antar wilayah (between theil index). Model pertama menetapkan variabel terikat adalah nilai indeks theil antar wilayah yang mencakup Barat Selatan, Tengah Tenggara, dan Timur Utara.

2. Kesenjangan Intra Wilayah (Within theil Index). Model kedua menetepkan variabel terikan adalah nilai indeks theil intra wilayah yang mencakup:

a. Wilayah Barat Selatan: Aceh Barat, Aceh Selatan, Nagan Raya, Aceh Jaya, Aceh Barat Daya, Singkil, dan Subulussalam 
b. Wilayah Timur Utara: Sabang, Banda Aceh, Aceh Besar, Pidie, Pidie Jaya, Bireuen, Lhokseumawe, Aceh Utara, Aceh Timur, Langsa, Aceh Tamiang

c. Wilayah Tengah Tenggara: Aceh Tengah, Aceh Tenggara, Bener Meriah, Gayo Lues.

Model estimasi data panel yang dilakukan menggunakan Fixed Effect Model (FEM) dengan pertimbangan jumlah cross section (3 wilayah) lebih kecil daripada jumlah time series (9 tahun). Hasil estimasi yang diperoleh dapat dijelaskan dalam tabel berikut.

Hasil estimasi persamaan model pertama menguji pengaruh dana OTSUS, belanja ekonomi, belanja publik, belanja kesehatan, dan belanja pendidikan terhadap indeks kesenjangan theil antar wilayah. Hasil persamaan model yang pertama ditemukan adanya pengaruh yang kuat antara masing-masing variabel bebas terhadap variabel terikat dengan koefisien determinasi sebesar 98 persen. Secara simultas variabel OTSUS, belanja ekonomi, belanja publik, belanja kesehatan, dan belanja pendidikan berpengaruh secara signifikan terhadap indeks kesenjangan antar wilayah dengan penerimaan taraf kepercayaan f-stat sebesar 99 persen. Namun demikian hasil pengujian secara parsial menginterpretasikan kecenderungan pengaruh yang berbeda-beda. Interetasi dapat dijelaskan berikut:

1. Dana OTSUS Aceh tidak berpengaruh secara signifikan dalam menurunkan kesenjangan antar wilayah. Maka dapat diinterpretasikan, perubahan jumlah penerimaan dana OTSUS tidak mampu menjadi determinan terhadap kesenjangan antar wilayah. Hal ini mengartikan bahwa dana OTSUS Aceh yang besar tidak mengarah pada perubahan kesenjangan antar wilayah. Jutstifikasi dari hasil persamaan ini menggambarkan alokasi dana OTSUS Aceh belum mampu memperbaiki kinerja pembangunan ekonomi antar wilayah Barat Selatan, Tengah Tenggara, dan Timur Utara. Potensi ekonomi dan konsentrasi pembangunan diwilayah Timur Utara diduga menjadi penyebab tingginya kesenjangan ekonomi di Aceh.

2. Belanja Ekonomi berpengaruh secara signifikan terhadap peningkatan indeks kesenjangan antar wilayah dengan taraf kepercayaan 95 persen. Nilai koefisien dari hasil persamaan sebesar 2,06 mendeskripsikan bahwa kenaikan belanja ekonomi sebesar Rp. 1 Milliar akan berdampak pada peningkatan kesenjangan antar wilayah sebesar 2,06 indeks point. Adanya dugaan yang kuat bahwa kesenjangan antar wilayah disebabkan oleh faktor konsentrasi ekonomi yang terpusat pada belanja ekonomi pada daerah pada daerah-daerah tertentu. Daerah-daerah yang dimaksud adalah wilayah Timur Utara yang berada pada jalur pesisir timur. Sementara wilayah Barat Selatan dan Tengah Tenggara masih tertinggal dari segi pembangunan ekonomi.

3. Belanja pelayanan publik tidak berpengaruh secara signifikan terhadap kesenjangan antar wilayah, di mana variabel ini secara parsial menghasilkan nilai t-stat di atas taraf kepercayaan yang ditetapkan. Secara umum, belanja pelayanan publik pada periode OTSUS sudah berjalan secara merata, yang ditandai dengan efisiensi birokrasi pelayan publik.

4. Belanja kesehatan tidak berpengaruh secara signifikan terhadap kesenjangan antar wilayah, dengan nilai t-stat diatar taraf kepercayaan. Telaah ini memberikan justifikasi bahwa periode OTSUS Aceh pada sisi belanja sektor kesehatan tidak mempengaruhi kesenjangan antar wilayah. Belanja kesehatan pada lingkup antar wilayah tidak relevan dalam menjelaskan situasi hubungan/interaksi dengan kesenjangan karena lingkup pelayanan BPJS terintegrasi pada seluruh kabupaten/kota.

5. Belanja pendidikan berpengaruh secara siginifikan terhadap kesenjangan antar wilayah di Provinsi Aceh. Koefisien sebesar -8,09 dapat diinterpretasikan, 
kenaikana belanja kesehatan sebesar Rp. 1 Milliar akan mampu menurunkan kesenjangan antar wilayah sebesar 8,09 indeks point. Variabel belanja kesehatan menjadi variabel yang tingkat penerimaan taraf kepercayaan paling tinggi, sebesar 99 persen. Hasil penelitian menunjukkan bahwa problematikan pendidikan di Aceh menjadi salah satu determinan kesenjangan antar wilayah. Hal ini bermakna peningkatan belanja pendidikan akan berdampak pada perbaikan kualitas Sumber Daya Manusia (SDM), yang pada gilirannya akan menurunkan kesenjangan antar wilayah.

\section{Tabel 2}

\section{Hasil Estimasi Model Kesenjangan Wilayah} Within Index Theil

\begin{tabular}{|c|c|c|c|}
\hline \multirow[t]{2}{*}{ Variabel } & \multicolumn{3}{|c|}{$\begin{array}{c}\text { Dependet Variabel Within Index } \\
\text { Theil }\end{array}$} \\
\hline & Koef & Std.Error & T-Stat \\
\hline $\begin{array}{l}\text { Constant } \\
\text { Parameter } \\
\text { (C) }\end{array}$ & 0,03 & 0,01 & $\begin{array}{c}4,7 \\
(* * *)\end{array}$ \\
\hline OTSUS & 3,25 & 1,09 & $\begin{array}{l}2,98 \\
(* * *)\end{array}$ \\
\hline $\begin{array}{l}\text { ECON_E } \\
\text { XP }\end{array}$ & 2,67 & 1,6 & $\begin{array}{c}1,66 \\
(*)\end{array}$ \\
\hline $\begin{array}{l}\text { PUBL_EX } \\
\text { P }\end{array}$ & 6,17 & 2,73 & $\begin{array}{l}2,26 \\
(* *)\end{array}$ \\
\hline $\begin{array}{l}\text { HEALTH_ } \\
\text { EXP }\end{array}$ & $-2,98$ & 9,33 & $\begin{array}{l}-3,2 \\
(* * *)\end{array}$ \\
\hline $\begin{array}{l}\text { EDUC_E } \\
\text { XP }\end{array}$ & $-4,84$ & 5,39 & $-0,9$ \\
\hline $\mathrm{R}^{2}$ & \multicolumn{3}{|c|}{0,99} \\
\hline F-Stat & \multicolumn{3}{|c|}{$\begin{array}{c}662,32 \\
(* * *) \\
\end{array}$} \\
\hline Dw-Stat & \multicolumn{3}{|c|}{1,6} \\
\hline
\end{tabular}

Sumber: Diolah oleh penulis dengan e-views ver 8.0

Keterangan: $* * *$ significant pada $\alpha 1 \%(\mathrm{p}<0.01)$; **significant pada $\alpha 5 \%(\mathrm{p}<0.05) ; *_{\text {significant }}$ pada $\alpha 10 \%(\mathrm{p}<0.1)$.

Model kedua dalam persamaan kesenjangan indeks theil dielaborasi dengan komposisi kesenjangan pada tingkat within region. Pengertiannya adalah Indeks kesenjangan dengan within region melihat kesenjangan yang terjadi didalam wilayah Barat Selatan, Timur Utara, dan Tengah Tenggara.

Hasil estimasi model kesenjangan intra wilayah (within index) lebih powerfull daripada model kesenjangan antar wilayah (between index). Hal ini dapat dilihat dari tingginya nilai R-Squared dan besaran f-stat pada uji secara simultan seluruh variabel. Deskripsi yang dapat dijelaskan dari hasil persamaan model within theil index adalah kesenjangan di Provinsi Aceh lebih dominan terjadi didalam intra wilayah Barat Selatan, Timur Utara, dan Tengah Tenggara. Interpretasi dari masing-masing variabel dapat dijelaskan dalam point berikut:

1. Dana OTSUS Aceh berpengaruh secara signifikan dalam meningkatkan kesenjangan pada intra wilayah di Provinsi Aceh, dengan taraf kepercayaan t-stat sebsar 99 persen. Peningkatan alokasi dana OTSUS sebesar Rp. 1 Milliar akan berdampak pada meningkatnya indeks kesenjangan intra wilayah sebesar 3,25 point indeks. Adanya dugaan bahwa alokasi dana OTSUS yang tidak berimbang mengakibatkan tingginya kesenjangan pada tingkat kabupaten/kota dalam masing-masing wilayah. Berbeda dengan hasil pada kesenjangan antar wilayah yang tidak signifikan, hasil estimasi model kedua ini menunjukkan bahwa terjadi alokasi dana OTSUS menjadi determinan yang dapat meningkatkan kesenjangan intra wilayah di Aceh.

2. Belanja ekonomi berpengaruh signifikan dan positif terhadap kesenjangan intra wilayah di provinsi Aceh dengan taraf kepercayaan 90 persen. Kenaikan belanja ekonomi sebesa Rp. 1 Milliar akan berdampak pada peningkatan indeks kesenjangan intra wilayah sebesar 2,67 point indeks. Hasil ini serupa dengan arah perolehan koefisien pada model kesenjangan antar wilayah. Interpretasinya adalah, kesenjangan yang terjadi di Aceh diduga disebabkan karena faktor konsentrasi belanja ekonomi yang berbeda-beda antar wilayah, dan adanya ketidakmampuan daerah dalam mengelola potensi ekonomi.

3. Belanja publik berpengaruh secara signifikan terhadap kesenjangan intra wilayah pada taraf 
kepercayaan 95 persen. Nilai koefisien sebesar 6,17 menginterpresikan, jika terjadi kenaikan belanja publik sebesar Rp. 1 Milliar, maka kesenjangan intra wilayah akan meningkat sebesar 6,17 point indeks. Hasil ini berbeda dengan model pertama kesenjangan antar wilayah, di mana pengaruh belanja publik tidak signifikan terhadap between theil indeks. Adanya dugaan yang menguat dari hasil yang berbeda ini bahwa kesenjangan pelayanan publik terjadi didalam lingkup intra wilayah di Kabupaten/kota, terutama pada daerah perbatasan dan daerah terpencil.

4. Belanja kesehatan berpengaruh secar signifikan dan negatif terhadap indeks kesenjangan intra wilayah di Provinsi Aceh, dengan penerimaan taraf kepercayaan 99 persen. Kenaikan belanja sektor kesehatan sebesar Rp. 1 Milliar akan diiringi dengan turunnya kesenjangan intra wilayah sebesar 2,98 point indeks. Pada model kedua belanja kesehatan menjadi determinan yang mampu menurunkan kesenjangan lingkup intra wilayah di Aceh. Maka dapat dijustifikan pemerataan belanja kesehatan sebagai kebutuhan dasar masyarakat, akan berdampak pada turunnya tingkat kesenjangan intra wilayah. Belanja kesehatan yang terintegrasi dengan program pelayanan kesehatan BPJS secara merata harus mampu menjangkat pada lingkup seluruh kabupaten/kota Provinsi Aceh.

5. Belanja pendidikan tidak berpengaruh terhadap kesenjangan pada lingkup intra wilayah. Hasil ini tampak berbeda dengan temuan pada model kesenjangan antar wilayah, dimana variabel belanja pendidikan berpengaruh signifikan dalam menurunkan kesenjangan antar wilayah. Meskipun tanda koefisien sama-sama negatif, namun pada model intra wilayah belanja pendidikan tampak tidak signifikan. Kondisi ini memberikan gambaran bahwa belanja pendidikan di lingkup kabupaten/kota belum terkoordinir dengan baik dan adanya perbedaan persepsi dalam penggunaan anggaran pendidikan untuk infrastruktur pendidikan dan perbaikan Sumber Daya Manusia (SDM) pengajar/guru.

\section{KESIMPULAN}

Berdasarkan penelitian yang telah dilakukan maka dapat disimpulkan bahwa disparitas wilayah yang terjadi di Provinsi Aceh terserap cukup besar pada kelompok intra wilayah (within inequality). Hal ini membuktikan bahwa kesenjangan tidak terjadi dalam lingkup antar wilayah di BaratSelatan, Tengah-Tenggara dan Timur Utara, namun terjadi dalam wilayah-wilayah itu sendiri.

Hasil estimasi pada model kesenjangan antar dan intra wilayah dengan Indeks Theil memperlihatkan respon arah yang berbeda. Secara umum alokasi dana OTSUS pada kelompok intra wilayah berdampak pada peningkatan kesenjangan. Pada kelompok antar wilayah tidak diperoleh arah dan hubungan yang signifikan antara dana OTSUS terhadap between theil index. Hasil penelitian menemukan, pengelolaan dana OTSUS yang berubah-ubah regulasinya akan berdampak pada peningkatan kesenjangan pembangunan.

Belanja pendidikan dan kesehatan menjadi variabel yang dapat menurunkan kesenjangan wilayah di Provinsi Aceh. Hasil temuan yang diperoleh menyimpulkan bahwa kesenjangan yang terjadi di Provinsi Aceh disebabkan karena faktor lemahnya penyediaan kebutuhan dasar, seperti pendidikan dan kesehatan. Oleh karena itu, pengelolaan dana OTSUS harus dilakukan secara tepat sasaran dalam meningkatkan aspek pelayahan pendidikan dan kesehatan di Provinsi Aceh.

\section{DAFTAR PUSTAKA}

[1] Badan Pusat Republik Indonesia, Tinjauan Regional Berdasarkan PDRB Kabupatn/Kota 2009-2015 Pulau Sumatra, Jakarta: BPS Pusat.

[2] Badan Pusat Statistik Aceh, Aceh dalam Angka 2000-2016, Aceh: BPS Provinsi Aceh.

[3] Bonet, J.A, Decentralization, Structural Change and Regional Disparities in Colombia, United States: University of Illinois at Urbana-Champaign, 2005 
[4] Dartanto dan Brodjinegoro, Dampak Desentralisasi Fiskal di Indonesia terhadap Pertumbuhan Ekonomi dan Disparitas Antar Daerah: Analisa Model Makro Ekonometrik Simultan. Jurnal Ekonomi dan Pembangunan Indonesia, Vol 4 No.1 Tahun 2003, hal 17-38.

[5] Lessmann, Christian, Fiscal Decentralization and regional Disparity: Evidence from Cross Section and Panel Data, Dresden Discussion Paper Series, Germany: Departement of Business and Economics Technische Universitat Dresden. 2006

[6] Liang, Zhicheng, Financial Reform, Growth and Regional Disparity in Post-Reform China,. France, CERDI University of Auvergne, 2007.

[7] Maulana, hafiizh, Analisis Disparitas di Provinsi Aceh Tahun 1992-2012: Pendekatan Model Konvergensi Wilayah. Univeristas Samudra Langsa, Jurnal Samudra Ekonomi dan Bisnis, Volume 7 Nomor 22016.

[8] Media Center DPRA, Qanun Nomor 2 Tahun 2008 Tentang Tata Cara Pengalokasian Dana Bagi Hasil Minyak dan Gas Bumi dan Penggunaan Dana Otonomi Khusus, Lembaran Daerah Nanggroe Aceh Darussalam Tahun 2008 Nomor 12, Tambahan Lembaran Daerah Nanggroe Aceh Darussalam Tahun 2008 Nomor 12.

[9] Qiao B., et. al.,, Growth and Equity Tradeoff in Decentralization Policy: China's Experience, Working paper, 02-16. Andrew Young School of Policy Studies, Georgia State University: Atlanta, 2002

[10] Republik Indonesia, Undang-Undang Nomor 11 Tahun 2006 Tentang Pemerintahan Aceh, Lembaran Negara Republik Indonesia Tahun 2006 Nomor 62, Tambahan Lembaran Negara Republik Indonesia Nomor 4633.

[11]Riyanto dan Siregar, Dampak Kebijakan Desentralisasi Fiskal Terhadap Perekonomian Daerah dan Pemerataan Antar Wilayah. Jurnal Kebijakan Ekonomi

[12] Universitas Indonesia, Vol 1 No. 1 Agustus 2005.

[13] Simanjuntak, Robert, Dana Alokasi Umum: Konsep, Hambatan, dan Prospek di Era Otonomi Daerah. Jakarta: Penerbit Buku Kompa, 2002.

[14] Todaro, Michael P. dan Stephen C. Smith., Pembangunan Ekonomi - Edisi Kesebelas, Jakarta: Erlangga, 2011.

[15] Yani, Ahmad, Hubungan Keuangan antara Pemerintah Pusat dan Daerah di Indonesia. Jakarta: Rajawali Persamaan, 2009 